\title{
Shell development, growth and sexual dimorphism in the Recent thecideide brachiopod Thecidellina meyeri sp. nov. from the Lesser Antilles, Caribbean
}

\author{
JANA HOFFMANN AND CARSTEN LÜTER \\ Museum für Naturkunde der Humboldt-Universität zu Berlin, Invalidenstrasse 43, 10115 Berlin, Germany
}

\begin{abstract}
A new thecideide brachiopod species, Thecidellina meyeri, is described from the southern Lesser Antilles (Aruba, Bonaire, Curaçao), Caribbean Sea, with unique morphological characters which clearly separate it from all other described species of Thecidellina in the region. A virtually complete series of ontogenetic stages is recorded, providing insight into the plasticity of shell development during growth in thecideide brachiopods and offering a well-defined standard for comparison with fossil material. Study of the soft tissue suggests that T. meyeri is dioecious, which contradicts the idea of Thecidellina to be hermaphroditic. The limited distribution and the unexpectedly high species diversity within the genus Thecidellina in the Caribbean region support the idea of allopatric speciation due to limited dispersal ability.
\end{abstract}

Keywords: shell development, growth, sexual dimorphism, Thecidellina meyeri sp. nov., Lesser Antilles, Caribbean Sea

Submitted 6 February 2008; accepted 26 June 2008; first published online 15 April 2009

\section{INTRロロபCTIDN}

Brachiopods are a group of marine sessile filter feeders represented by about 336 Recent species belonging to 100 genera (Logan, 2007). While of little interest to biologists, they are important to palaeontologists because of their long and impressive fossil record. Nevertheless it is essential to understand their way of living, their geographical distribution and diversity to evaluate fossil patterns.

Recent thecideide brachiopods are articulated brachiopods represented by five genera Thecidellina, Kakanuiella, Ospreyella, Pajaudina and Lacazella. Whereas Ospreyella, Pajaudina, Lacazella and probably Kakanuiella (see discussion Lüter, 2005) belong to the subfamily Lacazellinae Backhaus, 1959, Thecidellina is the only so far known Recent genus within the subfamily Thecidellininae Elliot, 1953. Thecidellina shows a worldwide distribution in marine subtropical and tropical waters. Representatives of this genus live in cryptic habitats of coral reefs, e.g. the undersides of foliaceous corals, overhangs, crevices, caves and subreef tunnels in association with other organisms such as sponges, ahermatypic corals, ectoprocts, cemented bivalves, serpulids and encrusting foraminiferans (Jackson et al., 1971; Logan, in press). These habitats are well-shaded to completely dark. Specimens of Thecidellina are cemented by their ventral valve to the substrate, e.g. dead corals, and thus lack a pedicle. Under optimal conditions a population of Thecidellina can reach densities of 10,600 specimens per square metre (Jackson et al., 1971; personal observation). However, their small body size of $2-10 \mathrm{~mm}$ and

Corresponding author:

J. Hoffmann

Email: jana.hoffmann@museum.hu-berlin.de strong macroscopic resemblance to other Recent thecideide brachipods makes it difficult to find and identify them in the field.

Thecidellina broods its larvae in two brood pouches located on either side of the median septum in the brachial lobes of the brachidium (Lüter, 2007). In each brood pouch larvae of different stages can be observed (personal observation). However, the process of fertilization and release of larvae is still poorly understood (Lüter, 2007). The lecithotrophic larvae of articulate brachiopods are supposed to have a low dispersal ability (James et al., 1992; Richardson, 1997), which might be reflected in the distinct distribution of different species of Thecidellina within a small geographical range, e.g. in the Caribbean (Lüter et al., in press).

So far eight species of Thecidellina have been described, three of them inhabiting the Atlantic and the Caribbean region. Unfortunately little taxonomic work on Recent thecideide brachiopods of the Atlantic region was carried out in the past. Until recently only one species, Thecidellina barretti (Davidson, 1864), was known from the north coast of Jamaica (Caribbean Sea), and was described as the type species of Thecidellina. Whereas most traditional investigations of Atlantic thecideide brachiopods were based on standard light microscopic techniques, the use of modern SEM technology provides new insigths into their unexpected morphological diversity. This led to the description of two new species, Thecidellina williamsi and Thecidellina bahamiensis, from the Cape Verde Islands and the Bahamas (Lüter et al., in press), which were previously thought to be conspecific with $T$. barretti.

This work aims to fill the gap in taxonomic knowledge about Recent thecideide brachiopods from the Caribbean region and describes an unusual new species of Thecidellina 
from the Lesser Antilles (ABC Islands) with special remarks on the variability of morphological characters, shell development and morphometrics.

This is the first study of a species of Thecidellina, which includes detailed information on sex-related characters, reproduction and larvae. Moreover it attempts to establish an exact terminology for description of morphological structures including detailed illustration of the terms used.

\section{MATERIALS AND METHDDS}

The material examined in this study originated from different sources (Table 1; Figure 1). D.L. Meyer collected most of the material by SCUBA diving in 1969, comprising a whole series of coral pieces from different localities in Curaçao covered with Thecidellina specimens of all developmental stages. Previous fixation in formaldehyde and subsequent drying led to the good preservation of the brachiopod's soft tissue. Additional material from Bonaire, Aruba and Curaçao (Vaersenbaai) was loaned from the Zoölogisch Museum, Universiteit van Amsterdam, Netherlands. It contains several dried individual valves (Bonaire and Curaçao) and one small piece of dead coral overgrown with brachiopods (Aruba). Another lot was loaned from the Smithsonian Institution, National Museum of Natural History, US originating from Curaçao containing a piece of dead coral with several specimens of Thecidellina and a lot with individual specimens all collected by J.B.C. Jackson.

Specimens of interest were carefully removed from the substrate. Ventral and dorsal valves were separated, but kept together. The sex (form and shape of gonads) and presence, number and size of larvae were documented using a Leica MZ 8 dissecting light microscope. For investigation of the shell morphology specimens were treated with $3 \%$ sodium hypochlorite and water to remove the soft tissue, afterwards air-dried and photographed. The Leica Application Suite Version 2.5.0 R1 MultiFocus system (Leica MZ 95 microscope, Leica DFC 420 digital camera) and Auto-Montage Essentials 5.03 generated extended depth field images of each investigated valve. Measurements were taken from adult specimens with the software ImageJ $1.37 \mathrm{~V}$ using the extended depth images. A subset of valves were mounted, sputter-coated with gold/palladium in a Polaron SC 7640 Sputter Coater and subsequently examined in a LEO VP 1450 scanning electron microscope. Digital images were edited and finally arranged as photographic panels using Adobe Photoshop ${ }^{\circledR} \mathrm{CS}_{2}$ and Adobe Illustrator ${ }^{\circledR} \mathrm{CS}_{2}$. Digital drawings were created with Adobe Illustrator ${ }^{\circledR} \mathrm{CS}_{2}$ and Adobe Photoshop ${ }^{\circledR} \mathrm{CS}_{2}$ (Coleman, 2003).

\section{RESULTS}

\section{Terminology}

Unfortunately, the terminology used for describing morphological structures of the shell of thecideide brachiopods is often insufficient. In some cases different terms are used for the same characters and vice versa, leading to confusion. Therefore, the most important terms regarding morphological structures used in this paper are illustrated (Figure 2A, B).
Furthermore newly described characters and related terms are introduced and figured.

$$
\begin{gathered}
\text { SYSTEMATICS } \\
\text { Order THECIDEIDA Elliott, } 1958 \\
\text { Superfamily THECIDEOIDEA Gray, } 1840 \\
\text { Family THECIDELLINIDAE Elliott, } 1958 \\
\text { Subfamily THECIDELLININAE Elliott, } 1953 \\
\text { Genus Thecidellina Thomson, } 1915 \\
\text { Thecidellina meyeri sp. nov. }
\end{gathered}
$$$$
\text { (Figures 3-5) }
$$$$
\text { T.? barretti: Jackson et al., } 1971 .
$$

\section{TYPE MATERIAL}

Holotype: adult female, valves separated, bleached and dried, SEM preparation. (Curaçao, Coralspecht; coordinates: $12^{\circ} 04^{\prime} 44.40^{\prime \prime} \mathrm{N} 68^{\circ} 53^{\prime} 49.20^{\prime \prime} \mathrm{W}$; water depth: 24-25 m) (ZMB Bra 2090, removed from ZMB Bra 2084a). Collected by D.L. Meyer, 5 September 1969.

Paratypes: 31 specimens ( 12 males, 18 females, 1 sex not determined), valves separated, bleached and dried, photographed (31 specimens), SEM preparation (2 adult specimens, 20 juveniles). (Curaçao, Coralspecht; coordinates: $12^{\circ} 04^{\prime} 44.40^{\prime \prime} \mathrm{N} 68^{\circ} 53^{\prime} 49.20^{\prime \prime} \mathrm{W}$; water depth: 24-25 m) (ZMB Bra 2084b, removed from ZMB Bra 2084a). Collected by D.L. Meyer, 5 September 1969.

ADDitional MATERIAL (FOR DETAILS SEE TABLE 1) Material is available from the Museum für Naturkunde der Humboldt-Universität zu Berlin, Germany from CuraçaoJan Thielbaai (ZMB Bra 2083a-c), Curaçao-Coralspecht (ZMB Bra 2084a-c, ZMB Bra 2085), Curaçao-Playa Kalki (ZMB Bra 2086a-c), Curaçao-Vaersenbaai (ZMB Bra 2088), Bonaire (ZMB Bra 2087) and Aruba (ZMB Bra 2089).

Additional material is available from the Zoölogisch Museum, Universiteit van Amsterdam, Netherlands from Curaçao-Vaersenbaai (ZMA Brac ooo153), Curaçao-Santa Martabaai (ZMA Brac 000168), Curaçao (ZMA Brac 000169), Bonaire (ZMA Brac 000154) and Aruba (ZMA Brac 000166) and from the Smithsonian Institution, National Museum of Natural History, Department of Palaeobiology, Washington DC, US from Curaçao (USNM 535886) and Curaçao-Playa Kalki (USNM 535887). In Jackson et al. (1971) one single coral slab from a coral rubble bottom is mentioned, collected in Coralspecht, Curaçao, in $24 \mathrm{~m}$ depth yielding 352 specimens. Unfortunately it was not noted where the material was deposited.

\section{DIAGNOSIS}

Large sized thecideide brachiopod. Dorsal valve intrabrachial ridge and brachial bridge not or slightly coalesced omitting a visceral gap; cardinal process massive, but very short. Ventral valve flat and roundish to deep and elongated; calcitic plate of hemispondylium ventrally not connected to ventral valve floor, arising from posterior or upper wall; prongs slender, exceptionally long, reaching beyond outer margin of ventral valve and teeth; ventral valve floor smooth; median ridge absent or only indicated.

\section{ETYMOLOGY}

Named after D.L. Meyer (Professor of Geology, Department of Geology, University of Cincinnati), who placed the precious brachiopod material from Curaçao at our disposal. 
Table 1. Material of Thecidellina meyeri examined. DV, dorsal valve; VV, ventral valve.

\begin{tabular}{|c|c|c|c|c|c|c|c|}
\hline Museum numbers & Locality & Coordinates & Depth (m) & Collector & Date & $\begin{array}{l}\text { Number of specimens total } \\
\text { (complete; DV; VV) }\end{array}$ & Remarks \\
\hline ZMB Bra 2090 & Curaçao, Coralspecht & $\begin{array}{l}12^{\circ} 04^{\prime} 44 \cdot 40^{\prime \prime} \mathrm{N} \\
68^{\circ} 53^{\prime} 49.20^{\prime \prime} \mathrm{W}\end{array}$ & $23.8-24.7$ & D.L. Meyer & 5 September 1969 & $1(1 ; 0 ; 0)$ & $\begin{array}{l}\text { Holotype picked from ZMB Bra } \\
\text { 2084a, SEM preparation }\end{array}$ \\
\hline ZMB Bra 2083a & Curaçao, Jan Thielbaai & $\begin{array}{l}12^{\circ} 04^{\prime} 33.60^{\prime \prime} \mathrm{N} \\
68^{\circ} 53^{\prime} 42^{\prime \prime} \mathrm{W}\end{array}$ & 17.8 & D.L. Meyer & 8 September 1969 & $>_{10}$ & Piece of dead coral-conglomerate \\
\hline ZMB Bra 2083b & Curaçao, Jan Thielbaai & $\begin{array}{l}12^{\circ} 04^{\prime} 33.60^{\prime \prime} \mathrm{N} \\
68^{\circ} 53^{\prime} 42^{\prime \prime} \mathrm{W}\end{array}$ & 17.8 & D.L. Meyer & 8 September 1969 & $31(0 ; 31 ; 31)$ & Separated and bleached valves \\
\hline ZMB Bra $2083 \mathrm{c}$ & Curaçao, Jan Thielbaai & $\begin{array}{l}12^{\circ} 04^{\prime} 33.60^{\prime \prime} \mathrm{N} \\
68^{\circ} 53^{\prime} 42^{\prime \prime} \mathrm{W}\end{array}$ & 17.8 & D.L. Meyer & 8 September 1969 & $7(1 ; 6 ; 2)$ & SEM preparation \\
\hline ZMB Bra 2084a & Curaçao, Coralspecht & $\begin{array}{l}12^{\circ} 04^{\prime} 44 \cdot 40^{\prime \prime} \mathrm{N} \\
68^{\circ} 53^{\prime} 49 \cdot 20^{\prime \prime} \mathrm{W}\end{array}$ & $23.8-24.7$ & D.L. Meyer & 5 September 1969 & $>_{30}$ & Piece of dead coral \\
\hline ZMB Bra 2084b & Curaçao, Coralspecht & $\begin{array}{l}12^{\circ} 04^{\prime} 44 \cdot 40^{\prime \prime} \mathrm{N} \\
68^{\circ} 53^{\prime} 49 \cdot 20^{\prime \prime} \mathrm{W}\end{array}$ & $23.8-24.7$ & D.L. Meyer & 5 September 1969 & $29(0 ; 29 ; 29)$ & $\begin{array}{l}\text { Paratypes separated and bleached } \\
\text { valves }\end{array}$ \\
\hline ZMB Bra $2084 \mathrm{c}$ & Curaçao, Coralspecht & $\begin{array}{l}12^{\circ} 04^{\prime} 44 \cdot 40^{\prime \prime} \mathrm{N} \\
68^{\circ} 53^{\prime} 49 \cdot 20^{\prime \prime} \mathrm{W}\end{array}$ & $23.8-24.7$ & D.L. Meyer & 5 September 1969 & $22(1 ; 15 ; 8)$ & Paratypes SEM preparation \\
\hline ZMB Bra 2085 & Curaçao, Coralspecht & $\begin{array}{l}12^{\circ} 04^{\prime} 44 \cdot 40^{\prime \prime} \mathrm{N} \\
68^{\circ} 53^{\prime} 49 \cdot 20^{\prime \prime} \mathrm{W}\end{array}$ & $23.8-24.7$ & D.L. Meyer & 5 September 1969 & $>_{30}$ & Piece of dead coral (branch) \\
\hline ZMB Bra 2086a & Curaçao, Playa Kalki & $\begin{array}{l}12^{\circ} 22^{\prime} 36 \cdot 3^{\prime \prime} \mathrm{N} \\
69^{\circ} 09^{\prime} 34 \cdot 3^{\prime \prime} \mathrm{W}\end{array}$ & 13.7 & D.L. Meyer & 27 July 1969 & $>_{30}$ & Piece of dead coral (branch) \\
\hline ZMB Bra 2086b & Curaçao, Playa Kalki & $\begin{array}{l}12^{\circ} 22^{\prime} 36 \cdot 3^{\prime \prime} \mathrm{N} \\
69^{\circ} 09^{\prime} 34 \cdot 3^{\prime \prime} \mathrm{W}\end{array}$ & 13.7 & D.L. Meyer & 27 July 1969 & $31(0 ; 31 ; 31)$ & Separated and bleached valves \\
\hline ZMB Bra 2086c & Curaçao, Playa Kalki & $\begin{array}{l}12^{\circ} 22^{\prime} 36 \cdot 3^{\prime \prime} \mathrm{N} \\
69^{\circ} 09^{\prime} 34 \cdot 3^{\prime \prime} \mathrm{W}\end{array}$ & 13.7 & D.L. Meyer & 27 July 1969 & $9(0 ; 9 ; 6)$ & SEM preparation \\
\hline ZMB Bra 2087 & Bonaire & - & $<_{30}$ & J. Buyse & 1965 & $1(0 ; 1 ; 1)$ & $\begin{array}{l}\text { SEM preparation, formerly deposited } \\
\text { as ZMA Brac } 000154\end{array}$ \\
\hline ZMB Bra 2088 & Curaçao, Vaersenbaai & $\begin{array}{l}\sim 12^{\circ} \text { o } 9^{\prime} \mathrm{N} \\
69^{\circ} \text { o } 1^{\prime} \mathrm{W}\end{array}$ & $15-20$ & A. Broeders & March 1972 & $1(0 ; 1 ; 1)$ & $\begin{array}{l}\text { SEM preparation, formerly deposited } \\
\text { as ZMA Brac 000153 }\end{array}$ \\
\hline ZMB Bra 2089 & $\begin{array}{l}\text { Aruba, Boca Cactus, } \\
\text { near Malmok }\end{array}$ & $\begin{array}{l}12^{\circ} 36^{\prime} \mathrm{N} \\
70^{\circ} 03^{\prime} \mathrm{W}\end{array}$ & 20 & - & January-February 1985 & $4(0 ; 3 ; 3)$ & $\begin{array}{l}\text { SEM preparation, formerly deposited } \\
\text { as ZMA Brac } 000166\end{array}$ \\
\hline ZMA Brac 000153 & Curaçao, Vaersenbaai & $\begin{array}{l}\sim 12^{\circ} \text { o } 9^{\prime} \mathrm{N} \\
69^{\circ} \text { o1 } 1^{\prime} \mathrm{W}\end{array}$ & $15-20$ & A. Broeders & March 1972 & $8(3 ; 2 ; 4)$ & \\
\hline ZMA Brac 000154 & Bonaire & - & $<30$ & J. Buyse & 1965 & $6(0 ; 2 ; 4)$ & \\
\hline ZMA Brac 000166 & $\begin{array}{l}\text { Aruba, Boca Cactus, } \\
\text { near Malmok }\end{array}$ & $\begin{array}{l}12^{\circ} 36^{\prime} \mathrm{N} \\
70^{\circ} 03^{\prime} \mathrm{W}\end{array}$ & 20 & I. Peeters & January-February 1985 & $\sim 40$ & Piece of dead scleractine coral \\
\hline ZMA Brac 000168 & $\begin{array}{l}\text { Santa Martabaai, } \\
\text { Curaçao }\end{array}$ & $\begin{array}{l}12^{\circ} 16^{\prime} 12^{\prime \prime} \mathrm{N} \\
69^{\circ} 07^{\prime} 47^{\prime \prime} \mathrm{W}\end{array}$ & 30 & K.M. de Jong & 1964 & $27(23 ; 1 ; 3)$ & \\
\hline ZMA Brac 000169 & Curaçao, West Indies & - & - & K.M. de Jong & - & $2(1 ; 0 ; 1)$ & \\
\hline USNM 535886 & Curaçao & - & - & J.B.C. Jackson & - & $4(4 ; 0 ; 0)$ & \\
\hline \multirow[t]{2}{*}{ USNM 535887} & $\begin{array}{l}\text { Curaçao, site VIII, } \\
\text { Playa Kalki }\end{array}$ & $\begin{array}{l}12^{\circ} 22^{\prime} 36.31^{\prime \prime} \mathrm{N} \\
69^{\circ} 09^{\prime} 34 \cdot 31^{\prime \prime} \mathrm{W}\end{array}$ & 18.3 & J.B.C. Jackson & 11 February 1991 & $\sim 15$ & On dead coral \\
\hline & Curaçao, Coralspecht & $\begin{array}{l}12^{\circ} 04^{\prime} 44,40^{\prime \prime} \mathrm{N} \\
68^{\circ} 53^{\prime} 49.20^{\prime \prime} \mathrm{W}\end{array}$ & 24 & - & - & 352 & $\begin{array}{l}\text { From coral rubble bottom, deposition } \\
\text { unclear }\end{array}$ \\
\hline
\end{tabular}




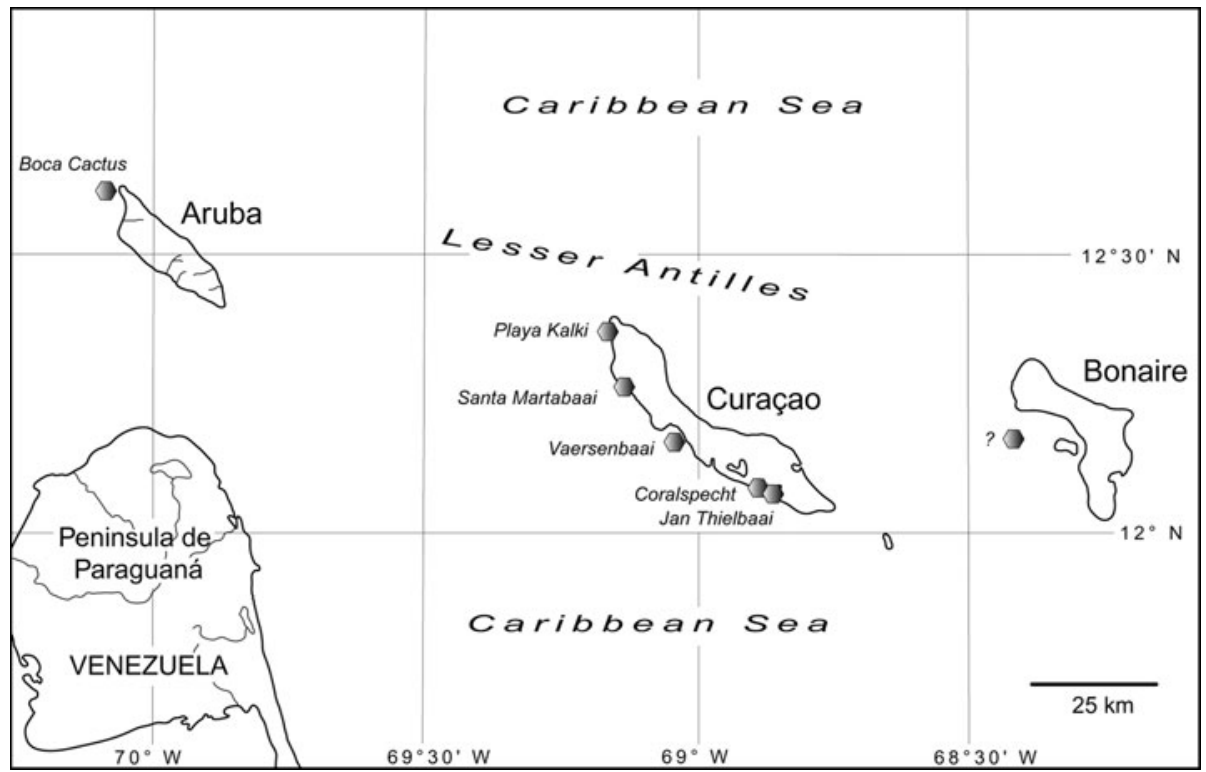

Fig. 1. Map of Aruba, Bonaire and Curaçao (ABC Islands), Lesser Antilles, with hexagons representing location of collecting sites of Thecidellina meyeri from which material was examined in this study.

A

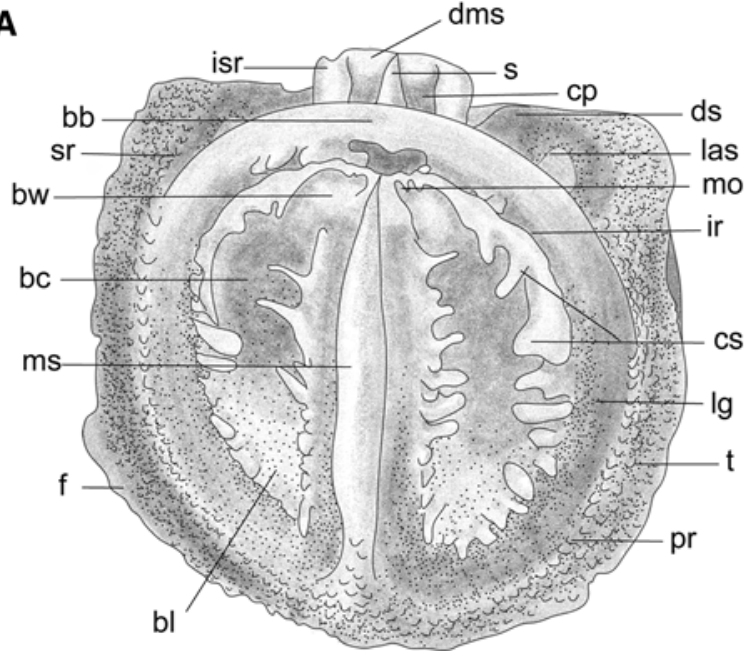

B

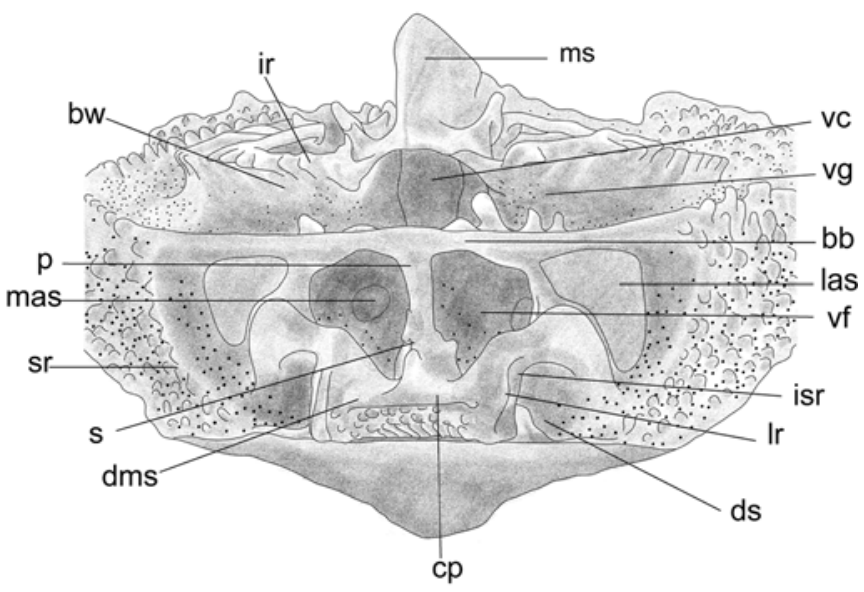

Fig. 2. Detailed illustration of main morphological characters and descriptive terms. (A) dorsal valve; (B) dorsal valve, posterior view. Abbreviations: bb, brachial bridge; bc, brachial cavity (location of brood pouch in females); bl interbrachial lobe; bw, body wall; cp; cardinal process; cs, canopying spicules; dms, diductor muscle scar; ds, dental sockets; f, flange; ir, intrabrachial ridge; isr, inner socket ridges; las, lateral adductor muscle scar (after Lacaze-Duthiers, 1861); lg, lophophore groove; lr, longitudinal ridges; mas, median adductor muscle scar (after Lacaze-Duthiers, 1861); mo, marsupial orifice (after Zumwalt, 1970); ms, median septum; p, pole; pr, peribrachial ridge; s, spur; sr, subperipheral rim (after Zumwalt, 1970); t, tubercle; vc, visceral cavity; vg, visceral gap; vf, visceral foramen.

\section{DESCRIPTION}

Large-sized thecideide brachiopod, longer than wide, endopunctate, biconvex, valves whitish to brownish, rectimarginate. Ventral valve (Figure ${ }_{3} \mathrm{~B}$ ) round to elongated depending on habitat, cemented to the substrate; cicatrix limited to the posterior part of the valve, variable in form and size; interarea flat (Figure $3 \mathrm{~B}, \mathrm{E}$ ), triangular with fine regular growth lines; hinge line straight; teeth sturdy, sub-triangular, large portions covered with secondary shell fibres (Figure $3 \mathrm{~K}, \mathrm{P}$ ); hemispondylium with calcitic plate (Figure $3 \mathrm{~N}$ ) ventrally connecting two diverging, dorsally-pointed strongly curved prongs (Figure E, R); calcitic plate ventrally not connected to ventral valve floor (Figure $3 \mathrm{E}$ ), rectangular, arising from posterior or upper delthyrial wall; prongs slender, exceptionally long, reaching beyond outer margin of ventral valve and teeth (Figure 3D); lateral adductor muscle scars large, elongated, postero-laterally of either tooth (Figure ${ }_{3} \mathrm{E}$ ); delthyrial cavity sometimes extending beyond hemispondylium depending on shape of ventral valve; ventral valve floor smooth with irregular inconspicuous punctae; median ridge absent or rudimentary, dividing posterior part of the valve floor into two shallow gonad pits.

Dorsal valve smaller than ventral valve, lid-like, roundish to oval, slightly convex; entire interior structures successively 
raised towards the back (Figure ${ }_{3} \mathrm{C}$ ); median septum narrow with broad tuberculated crest, posteriorly ascending, anteriorly and posteriorly tapering; intrabrachial ridge clearly defined, raised, outer margins dentate (Figure $3 \mathrm{~A}, \mathrm{M}$ ), posterior margin with marsupial orifice on either side of the median septum (Figure $3 \mathrm{~F}$ ); intrabrachial lobes with deep pits (=brachial cavity), in females location of brood pouches (Figure $3 \mathrm{~A}$ ); posterior floor raised, canopying visceral cavity forming the body wall; canopying spicules, if present, slender, rarely interconnected; peribrachial ridge regularly tuberculated, posteriorly descending to brachial bridge without tubercles; brachial bridge broad with clearly defined lophophore muscle scars (Figure $3 \mathrm{~F}$ ), touching ventral valve floor if valve closed, supported by slender calcitic pole (Figure $3 \mathrm{H}$ ) with irregular caudal outgrowths forming an ill-defined spur (Figure $3 \mathrm{~L}$ ) and regular three-dimensional apical outgrowths buttressing the posterior part of the gastrointestinal tract (Figure $3 \mathrm{~L} \&$ Figure $4 \mathrm{P}$ ); large visceral gap between brachial bridge and intrabrachial ridge (Figure $3 \mathrm{~A}, \mathrm{~F}, \mathrm{G}$ ); inner portion of brachial bridge with illdefined outgrowths (Figure $3 \mathrm{O}$ ), only in largest specimens connected to intrabrachial ridge on either side of the median septum; cardinal process massive (Figure $3 \mathrm{~A}, \mathrm{~L}$ ), but very short, trilobate (Figure $3 \mathrm{~L}$ ); medio-posterior margin prominent, straight, serving as muscle attachment site for diductor muscles; dorsal face with regular rows of tubercles (Figure $3 \mathrm{H}$ ); lateral lobes (=inner socket ridges) bulging, covered with fibrous secondary shell layer, lateral margins with longitudinal ridges (Figure $3 \mathrm{~L}$ ); median lobe produced and connected to supporting pole of brachial bridge; pole separating two large and reverse drop shaped visceral foramina (Figure $3 \mathrm{G}, \mathrm{H}$ ); body wall with two inconspicuous median adductor muscle scars opposite to visceral foramina; large lateral adductor muscle scars on either side of the cardinal process, subtriangular.

Ventral and dorsal valve linked with hinge comprising hemispondylium and teeth of ventral valve and sockets and cardinal process of dorsal valve, allowing specimen to open the valve in almost a 90-degree angle. Prongs of hemispondylium reaching far into each of the visceral foramina when valve is closed (Figure $3 \mathrm{I}$ ).

\section{HABITAT}

Specimens of Thecidellina meyeri were collected from the fore reef slope (Meyer, personal communication). They are attached to dead corals, preferably the underside of foliaceous corals, and dead coral conglomerates. The specimens occur in a characteristic community of organisms (Figure $5 \mathrm{~A}$ ) such as sponges, bryozoans, foraminifers, serpulids and ahermatypic corals (e.g. Caryophyliidae) in densities of about 10,000 specimens $\mathrm{m}^{-2}$ and are the dominant taxa in this community (Figure 5A).

\section{Shell ontogeny}

Numerous well preserved specimens examined in this study allow a detailed description of the dorsal valve development of Thecidellina meyeri to be made. Whereas the ventral valve appearance changes little during ontogeny and main characteristics are developed early, the dorsal valve characters undergo major changes during shell development and growth, which could easily be regarded as interspecific differences and thus are essential for identification.

The dorsal valve of specimen $1(\mathrm{~L}=0.82 \mathrm{~mm}$; W $=$ $0.87 \mathrm{~mm}$; Figure $4 \mathrm{~A}, \mathrm{~K}$ ) represents the earliest stage in shell development observed in the material examined. The valve floor is slightly convex and exhibits regular, almost concentric rows of punctae. The bilobed cardinal process is prominent and slightly projecting above the hinge line. The outer lobes are covered with secondary shell fibres. The lateral adductor muscle scars and dental sockets are present and clearly defined. The peribrachial ridge is defined by a row of strong tubercles. The lophophore bridge is simple and spans the posterior part of the visceral cavity. The well developed postero-lateral subperipheral rim is a characteristic for this stage. The rim is the posterior extension of the peribrachial ridge reaching up to the hinge margin. It consists of a row of elevated tubercles and connects the lateral edges of the bridge to the hinge margin (see Zumwalt, 1970). Two distinct and laterally flattened spikes, the tips of which are pointed postero-laterally, originate in the centre of the valve floor.

The dorsal valve of specimen $2(\mathrm{~L}=1.18 \mathrm{~mm}$; $\mathrm{W}=$ $1.24 \mathrm{~mm}$; Figure $4 \mathrm{~B}, \mathrm{~L})$ represents a more advanced stage than specimen 1 . The cardinal process shows two lateral and one median lobe whereas only the outer lobes are covered with secondary shell material. The median lobe is narrow and posteriorly flattened forming a small platform for diductor muscle attachment. The bridge is slightly pointed mediodorsally. The median septum is indicated and the intrabrachial ridge starts to grow. The lateral flanges of the peribrachial ridge are well developed. The anterior part of the peribrachial ridge exhibits multiplied rows of strong peripheral tubercles.

In specimen $3\left(\mathrm{~L}=1.85 \mathrm{~mm} ; \mathrm{W}=2.06 \mathrm{~mm}\right.$; Figure ${ }_{4} \mathrm{C}$, G, M) the median part of the bridge is pointed dorsally, projects far into the visceral cavity and almost reaches the enlarged median lobe of the cardinal process. The posterolateral subperipheral rim is inconspicuous. The median septum and the intrabrachial ridge are well defined and the intrabrachial lobes are indicated. The brachial structures are increasing antero-posteriorly in height and thus dominating the profile of the dorsal valve.

In specimen $4(\mathrm{~L}=2.52 \mathrm{~mm}$; W $=2.70 \mathrm{~mm}$; Figure $4 \mathrm{D}$, $\mathrm{H}, \mathrm{N})$ the median part of the bridge and the median lobe of cardinal process are fused forming a supporting structure of the bridge, the pole. At the point of fusion the posterior directed spur arises formed by the distal end of the pointed portion of the brachial bridge. The pole divides the visceral foramen into two reverse drop shaped foramina. The median septum is narrow and blade-like, separating the two intrabrachial lobes. The intrabrachial ridge is well developed with more or less regular spikes. The body wall consisting of the posterior part of the median septum and the flanking parts of the intrabrachial ridge is canopying parts of the visceral cavity leaving a visceral gap. On the opposite inner margin of the bridge, on either side of the visceral foramen, ill-defined outgrowths start to develop pointing anteriorly into the visceral gap. The peribrachial ridge is well defined and fused with the anterior-most tip of the median septum forming an inwardly directed triangle $\left(^{*}\right)$ covered with strong tubercles.

Specimen $5(\mathrm{~L}=3.57 \mathrm{~mm} ; \mathrm{W}=3.97 \mathrm{~mm}$; Figure $4 \mathrm{E})$ represents the most advanced juvenile stage found in the material. In most characters it is like specimen 4 but shell structures are more developed. The outer margin of the intrabrachial ridge is regularly dentate and the intrabrachial lobes are completely developed. 

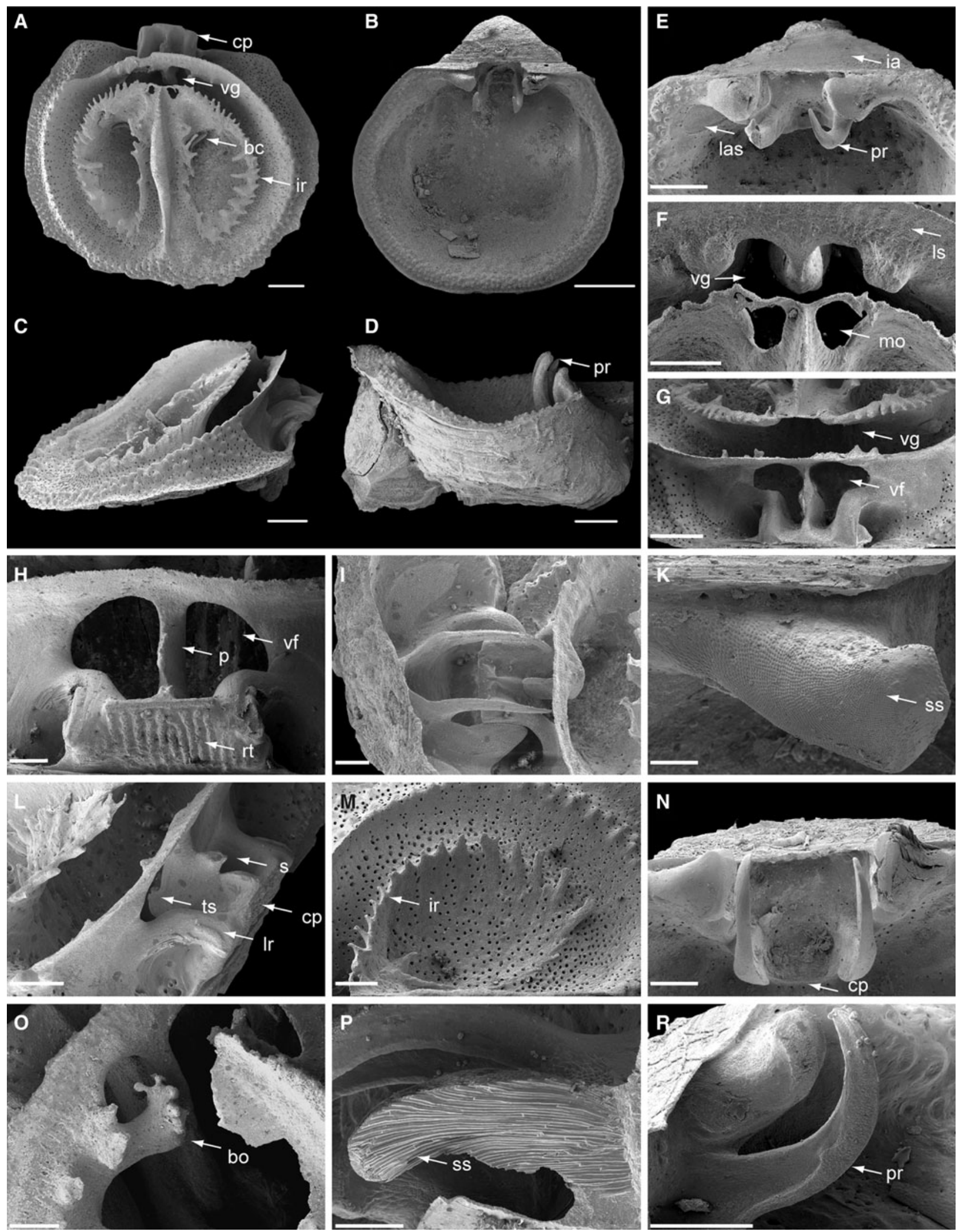

Fig. 3. (See next page for legend.) 
Fig. 3. (Legend; see previous page for figure.) Thecidellina meyeri sp. nov. (A) dorsal valve. Notice the large visceral gap (vg), the dentate intrabrachial ridge (ir) and the deep brachial cavity (bc), the location of the brood pouch (female, holotype) (ZMB Bra 209o); (B) ventral valve. The outline of the valve is drop shaped and the valve floor is smooth (female, holotype) (ZMB Bra 2090); (C) dorsal valve, lateral view. The posterior part of the valve is successively raised resulting in a triangular profile (female, holotype) (ZMB Bra 2090); (D) ventral valve, lateral view. A juvenile specimen is attached to the ventral valve illustrating the density of the population. The characteristic long and slender prongs (pr) of the hemispondylium are reaching far beyond the outer margin of the adult ventral valve (male, paratype) (ZMB Bra 2084c); (E) ventral valve, hemispondylium. The interarea (ia) is flat and shows characteristic transversal growth lines. There is no trace of a pseudodeltidium. On either side of the hemispondylium are large lateral adductor muscle scars (las) (ZMB Bra 2089); (F) dorsal valve. There is a large visceral gap (vg) between the brachial bridge with its anterior directed outgrowths and the intrabrachial ridge. The lophophore muscle scars (ls) on the brachial bridge are distinct. The posterior margin of the intrabrachial ridge bears two marsupial orifices (mo) on either side of the median septum (ZMB Bra 2089); (G) dorsal valve, posterior view. There is a large visceral gap (vg) and the posterior portion of the intrabrachial ridge is canopying the visceral cavity (female, holotype) (ZMB Bra 209o); (H) dorsal valve, posterior view. The dorsal face of the cardinal process is provided with longitudinal rows of tubercles (rt). The brachial bridge is supported by a calcitic pole (p) with large visceral foramina (vf) on either side (ZMB Bra 2086c); (I) dorsal and ventral valve. The hinge is formed by portions of the dorsal valve (cardinal process, hinge line) and the ventral valve (hemispondylium with prongs). The prongs reach into the visceral cavity via the visceral foramina (ZMB Bra 2086c); (K) ventral valve. There are two teeth on either side of the hemispondylium. They are covered with secondary shell material (ss) (female, holotype) (ZMB Bra 2090); (L) dorsal valve, posterior and lateral view. The calcitic pole of the cardinal process is formed by portions of the median lobe of the cardinal process and portions of the brachial bridge, which fuse medially. On the anterior face of the pole a three-dimensional structure (ts) is located reaching into the visceral cavity. The lateral lobes of the cardinal process are covered with secondary shell material and show longitudinal ridges (lr). The spur (s) is located on the posterior face of the pole (ZMB Bra 2086c); (M) dorsal valve. The intrabrachial ridge (ir) is clearly dentate particularly in juvenile specimens (juvenile, paratype) (ZMB Bra 2084c); (N) ventral valve. The hemispondylium consists of two slender prongs connected by a calcitic plate (pl), which is not fused with the valve floor (female, holotype) (ZMB Bra 2090); (O) dorsal valve. The inner portion of the bridge shows ill-defined outgrowths (bo) spanning the visceral gap (male) (ZMB Bra 2083c); (P) ventral valve. This is a longitudinal section of a tooth, illustrating their formation by secondary shell material (ss) (juvenile, paratype) (ZMB Bra 2084c); (R) ventral valve. Lateral view of the hemispondylium showing the abnormal length of the prongs in relation to the tooth (juvenile, paratype) (ZMB Bra 2084c). Scale bars: A-E $=500 \mu m$; $\mathrm{F}$, $\mathrm{L}$, $\mathrm{L}-\mathrm{N}$, $\mathrm{R}=300 \mu \mathrm{m} ; \mathrm{H}, \mathrm{O}=200 \mu \mathrm{m} ; \mathrm{I}=150 \mu \mathrm{m} ; \mathrm{K}, \mathrm{P}=100 \mu \mathrm{m}$.

In adult specimens (Figure ${ }_{4} \mathrm{~F}, \mathrm{I}, \mathrm{O}, \mathrm{P}$ ) the irregular outgrowths of the inner margin of the bridge may fuse completely or incompletely to portions of the intrabrachial ridge on either side of the median septum. In some very large specimens the pole is detached from the bridge and free-standing, forming a three-dimensional triangular structure (Figure $3 \mathrm{~L} ; 4 \mathrm{P}$ ). The median septum is broad and tuberculated (Figure $4 \mathrm{~F}$ ).

\section{Intraspecific variability}

In thecideides, intraspecific variability of morphological structures is mainly related to ongoing growth, the surface structure of the substrate and-in few cases-to sexual dimorphism.

The overall shape of the ventral valve strongly depends on the surface relief of the substrate and the influence of adjacent thecideide shells. The shape can vary from flat and roundish (Figure $5 \mathrm{~B}$ ) to deep and elongated. There are some variable characters related to shell growth itself: (1) the caudal outgrowths of the brachial bridge may be fused with the intrabrachial ridge in very large and old specimens, forming a kind of supporting structure (Figure $4 \mathrm{P}$ ); (2) the pole usually connects the brachial bridge to the floor of the cardinal process, but can be detached from the brachial bridge in very large and old specimens (Figure $4 \mathrm{P}$ ); and $(3)$ the median septum is bladelike in juveniles and young adults (Figure ${ }_{4} \mathrm{E}$ ), but broadens successively with growth (Figure $3 \mathrm{~A} \&$ Figure $4 \mathrm{~F}$ ). Another character is related to the sex of the individual. Females form long and slender canopying spicules spanning the brood cavities. In males canopying spicules are usually absent.

\section{Reproduction}

Specimen of Thecidellina meyeri brood their larvae in their two brood pouches. A maximum of 9 larvae in each of the brood pouches was counted, the mean value is $5.4 \pm 2$ larvae $(\mathrm{N}=20)$. The size of the larvae ranges from $0.23-0.62 \mathrm{~mm}$, the mean value is $0.39 \pm 0.08 \mathrm{~mm}(\mathrm{~N}=56)$. It has to be acknowledged that fixation, drying and the subsequent transfer into water might have led to the shrinking of the soft tissue and larvae. However, in vivo this might cause an even larger but not smaller size of the larvae. There is no correlation between female shell size and number of larvae. Brooding activity (=presence of larvae) could be observed from the end of July to the beginning of September. The different sexes can be clearly distinguished by the shape of the gonads and the presence and absence of larvae. The gonads are located in the ventral valve and can be recognized in vivo by their orange colour. Male gonads are undifferentiated, long and slender almost reaching the anterior margin of the ventral valve. Female gonads are located in the posterior half of the ventral valve and consist of single large eggs forming a grapelike structure. The larvae in the brood pouch are of the same colour as the gonads and clearly visible underneath the lophophore of the female; they have about the same size as the eggs.

\section{Morphometrics (Table 2)}

Thecidellina meyeri is a large-sized thecideide brachiopod. It is the largest species of Thecidellina in the Caribbean region, with a maximum length of $7.7 \mathrm{~mm}$. There is no difference in size between the males and females in mean values. The angle of the interarea has a wide range not dependent on size, but on the variable shape of the ventral valve.

\section{DISCUSSION}

\section{Morphology and taxonomy}

Thecidellina is known from the Caribbean region since the description of Thecidellina barretti by Davidson (1864). Until recently it was believed that all specimens of Thecidellina found in the Caribbean region (Cooper, 1977; Dall, 1885-1886, 1920; Jackson et al., 1971; Logan, 1977, 1981, 1990; Pajaud, 1970) and the Cape Verde Islands (Logan, 1993) are conspecific, although the maximum distance between populations from Jamaica to the Cape Verde Islands is about $5500 \mathrm{~km}$ (Lüter et al., in press). This is due to insufficient morphological investigations, few valuable characters for species discrimination (Lee \& Robinson, 2003) and strong macroscopic resemblance of the specimens. However, Lüter et al. (in press) described two new species of 

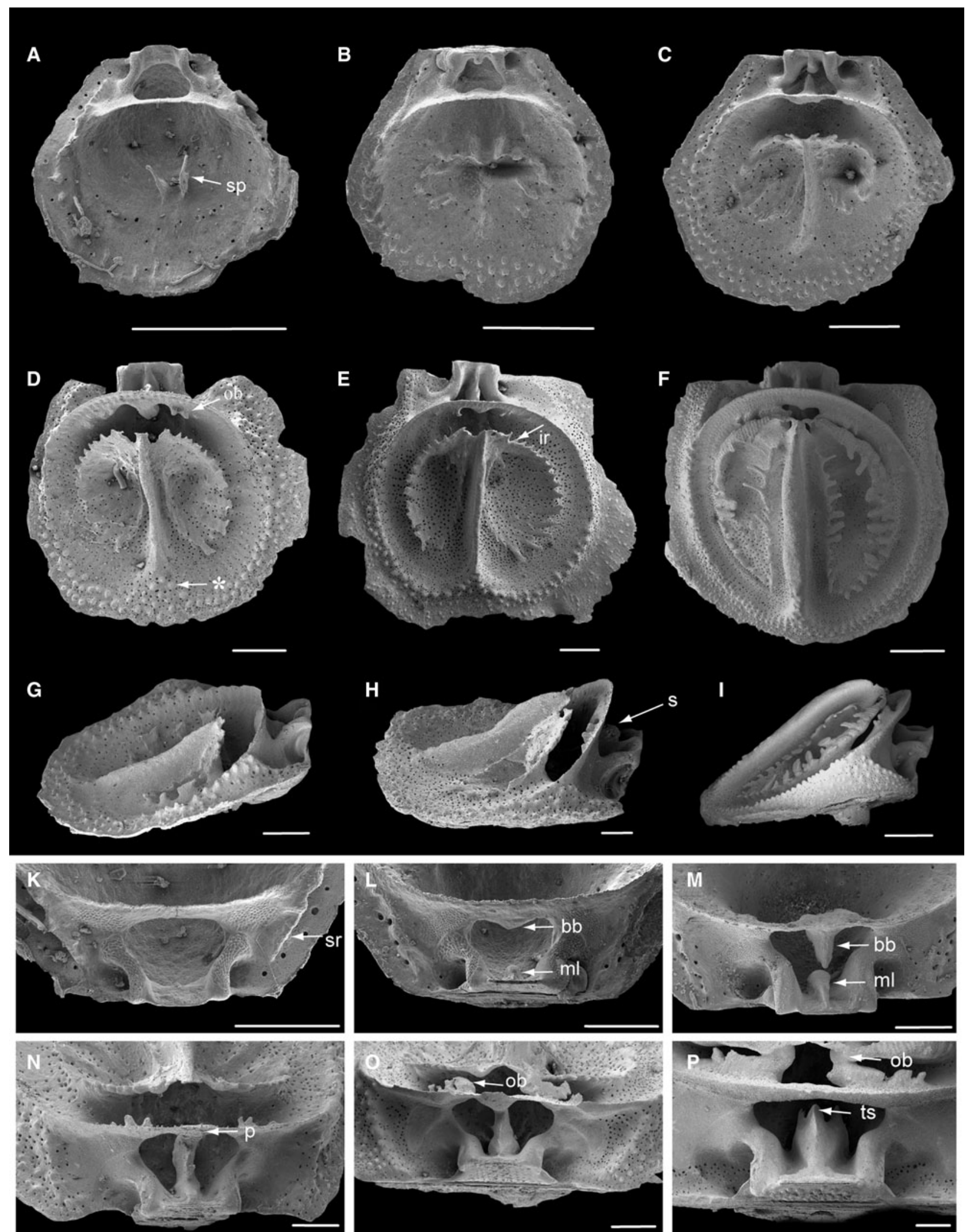

Fig. 4. (See next page for legend.) 
Fig. 4. (Legend; see previous page for figure.) Thecidellina meyeri sp. nov.--shell development. (A) specimen 1, dorsal valve, juvenile (ZMB Bra $2083 \mathrm{C}$ ). In the centre of the valve are two spikes (sp) representing the start of the development of the brachidium; (B) specimen 2, juvenile, paratype, dorsal valve (ZMB Bra 2084c). In this more advanced stage the median septum starts to evolve and the intrabrachial ridge is indicated; (C) specimen 3 , dorsal valve, juvenile, paratype (ZMB Bra $2084 \mathrm{C}$ ). Here the brachial lobes are already formed and the median septum is well developed; (D) specimen 4, dorsal valve, juvenile, paratype (ZMB Bra $2084 \mathrm{c}$ ). In this specimen the median septum fuses with the peribrachial ridge $(*)$ on the anterior margin of the valve; (E) specimen 5 , dorsal valve, juvenile, paratype (ZMB Bra 2084c). The intrabrachial ridge is well developed and dentate. The peribrachial ridge is prominent and bounded by regularly arranged tubercles; ( $F)$ dorsal valve, adult specimen (ZMB Bra 2089). In this adult specimen all main characters of the brachidium and adjacent structures are well developed. The canopying spicules span parts of the brachial cavity. Lophophore muscle scars are clearly visible; (G) specimen 3, dorsal valve, lateral view, juvenile, paratype (ZMB Bra 2084c). The posterior margin of the cardinal process corresponds to the hinge line in early stages. The posteriorly pointed median part of the brachial bridge is about to fuse with the median lobe of the cardinal process; $(\mathrm{H})$ specimen 4, dorsal valve, lateral view, juvenile, paratype (ZMB Bra $2084 \mathrm{c}$ ). The median part of the brachial bridge and the median lobe of the cardinal process are fused. The point of fusion forms the posterior directed spur (s) of the calcitic pole; (I) dorsal valve, lateral view, adult specimen (ZMB Bra 2089). The valve has its characteristic triangular profile. The cardinal process is very short and the apical outgrowths of the brachial bridge are fused with the intrabrachial ridge. The visceral gap is narrowed by successive growth. The canopying spicules are ventrally flattened due to the limited space in the ventral valve; (K) specimen 1, dorsal valve, posterior view, juvenile (ZMB Bra $2083 \mathrm{c}$ ). In this early stage the subperipheral rim (sr) is clearly visible; (L) specimen 2, dorsal valve, posterior view, juvenile, paratype (ZMB Bra $2084 \mathrm{c}$ ). The median lobe of the cardinal process is indicated and the median portion of the brachial bridge (bb) is pointed in direction of the median lobe ( $\mathrm{ml}$ ) of the cardinal process; (M) specimen 3, dorsal valve, posterior view, juvenile, paratype (ZMB Bra 2084c). The portions of the median lobe (ml) of the cardinal process and the brachial bridge (bb) are about to fuse with each other. The subperipheral rim is fading; $(\mathrm{N})$ specimen 4, dorsal valve, posterior view, juvenile, paratype (ZMB Bra $2084 \mathrm{c}$ ). The calcitic pole (p) is formed by the fusion of parts of the cardinal process and the brachial bridge. On the anterior face of the brachial bridge the first anterior directed outgrowths start to evolve; $(\mathrm{O})$ dorsal valve, posterior view, adult specimen (ZMB Bra 2086c). The outgrowths of the brachial bridge (ob) are partly fused with the intrabrachial ridge. Portions of the anterior face of the pole start to grow into the visceral cavity; (P) dorsal valve, posterior view, adult specimen (ZMB Bra 2089). The outgrowths of the brachial bridge (ob) are entirely fused with the intrabrachial ridge around the mouth region of the specimen, forming a kind of supporting structure. In this specimen the rare event takes place, that the calcitic pole is detached from the brachial bridge and the apical outgrowths of the pole form a three-dimensional supporting structure (ts) of the gastrointestinal tract. Scale bars: $\mathrm{F}, \mathrm{I}=1000 \mu \mathrm{m}$; $\mathrm{A}-\mathrm{E}, \mathrm{O}=$ $500 \mu \mathrm{m} ; \mathrm{N}, \mathrm{G}, \mathrm{H}, \mathrm{P}=300 \mu \mathrm{m} ; \mathrm{K}-\mathrm{M}=200 \mu \mathrm{m}$.

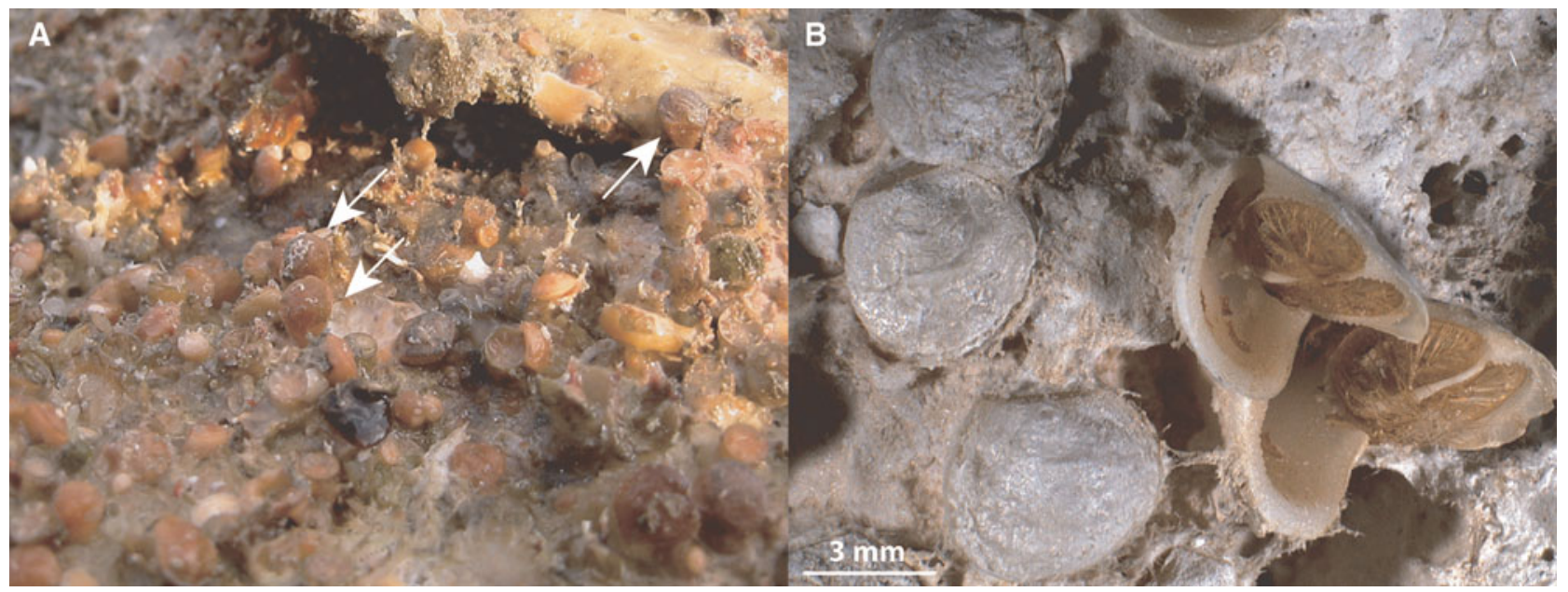

Fig. 5. Thecidellina meyeri sp. nov. (A) Thecidellina meyeri sp. nov. on coral substrate. Specimens of T. meyeri (arrowed) occur in high densities and with a characteristic fauna (photographed by B. Leysner); (B) specimens of T. meyeri with vestiges of soft tissue e.g. lophophore (Curaçao) (ZMB Bra 2086a).

Thecidellina from the Bahamas, Thecidellina bahamiensis Lüter \& Logan and from the Cape Verde Islands, Thecidellina williamsi Lüter \& Logan based on extensive studies of the shell morphology using electron microscopy. A new set of morphological characters for species discrimination was offered. The present study ties up to the previous one based on rich material for comparative studies from the $\mathrm{ABC}$ Islands (Aruba, Bonaire and Curaçao) close to the Venezuelan mainland. This well-preserved material has led to the description of Thecidellina meyeri, a very unusual largesized thecideide brachiopod. However, Thecidellina meyeri does not resemble one of the known species of Thecidellina, T. barretti, T. bahamiensis and T. williamsi, in the Atlantic and Caribbean region. Actually, most of its morphological characters are unique among Thecidellina spp. worldwide such as: (1) the stout cardinal process with clearly visible longitudinal rows of tubercles; (2) the very long and slender prongs of the hemispondylium; (3) the lack of a broad connection of the brachial bridge to the intrabrachial ridge; (4) the very large visceral foramina divided by a slender calcitic pole; and (5) the highly raised median septum.

The detailed documentation of the shell ontogeny of Thecidellina meyeri illustrates that some of the morphological characters undergo changes during development, whereas some of the shell structures change significanly during development, e.g. pole, median septum, connection between brachial bridge and intrabrachial ridge. This illustrates the plasticity of shell development in Thecidellina and shows how important it is to document the different developmental stages (see Lee \& Robinson, 2003). Zumwalt (1970) did the first detailed description of the shell ontogeny of a Recent representative of the genus Thecidellina, Thecidellina congregata, from Eniwetok Atoll, Marshall Islands, which, however, was never published. Logan (in press) describes and illustrates the dorsal valve ontogeny in $T$. congregata from Saipan. Based on these studies it became apparent that comparable developmental stages in $T$. meyeri and T. congregata occur in specimens of about the same size. However, the development of important diagnostic 
Table 2. Measurements of the shell of Thecidellina meyeri giving the range and the mean values with standard deviations (in parentheses).

\begin{tabular}{|c|c|c|c|c|c|}
\hline & \multicolumn{2}{|c|}{ DV } & \multicolumn{2}{|c|}{ VV } & \multirow[t]{2}{*}{ Angle $\left({ }^{\circ}\right)$} \\
\hline & $\mathbf{L}(\mathbf{m m})$ & $\mathrm{W}(\mathrm{mm})$ & $\mathbf{L}(\mathbf{m m})$ & $\mathrm{W}(\mathrm{mm})$ & \\
\hline Female $(\mathrm{N}=24)$ & $3.4-5.3(4.4 \pm 0.4)$ & $3.8-5.9(4.7 \pm 0.4)$ & $3.9-6.8(5.4 \pm 0.8)$ & $3.4-5.8(4.7 \pm 0.6)$ & $66-133$ \\
\hline Male $(\mathrm{N}=23)$ & $2.9-6.0(4.4 \pm 0.6)$ & $3.8-6.2(4.7 \pm 0.6)$ & $2.6-7.7(5.6 \pm 1.2)$ & $2.9-5.8(4.7 \pm 0.6)$ & $69-133$ \\
\hline
\end{tabular}

DV, dorsal valve; VV, ventral valve; L, length; W, width.

characters in T. congregata, e.g. the shape of the calcitic pole and the presence or absence of a visceral gap, differs from Thecidellina meyeri in some details. Interestingly the development of these diagnostic characters already takes place in the first ontogenetic stages of both species. Thus they seem to be reliable and not influenced by intraspecific variability, which underlines their importance for species identification. A detailed study of ontogenetic series from different species will be part of another paper on the comparison of developmental traits in the genus Thecidellina, which may reveal hitherto unrecognized patterns.

\section{Reproduction and dispersal}

Previously, species of Thecidellina have been regarded as hermaphroditic (James et al., 1992; Lee \& Robinson, 2003; James, unpublished data). However, this and other studies (see Zumwalt, 1970; Lüter, 2007) suggest Thecidellina to be dioecious. Actually, there is some evidence for sexual dimorphism in Thecidellina meyeri. First of all the shape of the gonads (see above) and the presence of larvae are the most reliable characters for sex identification. Male and female gonads never occur simultaneously in the same specimen and the presence of larvae is always connected to the presence of female gonads. However, very often only shells without any soft tissue are available. It is almost impossible to distinguish between males and females relying on the shell only. There are no major size differences between males and females (Table 2) and only the presence of the slender and fragile canopying spicules, which are often destroyed or damaged, are characteristic for brooding females. The size of the larvae corresponds with other data on Thecidellina sp. (Lüter, 2001), but disagrees with the size of larvae suggested by James et al. (1992). He reported an egg diameter of about $0.02 \mathrm{~mm}$ in Thecidellina barretti.

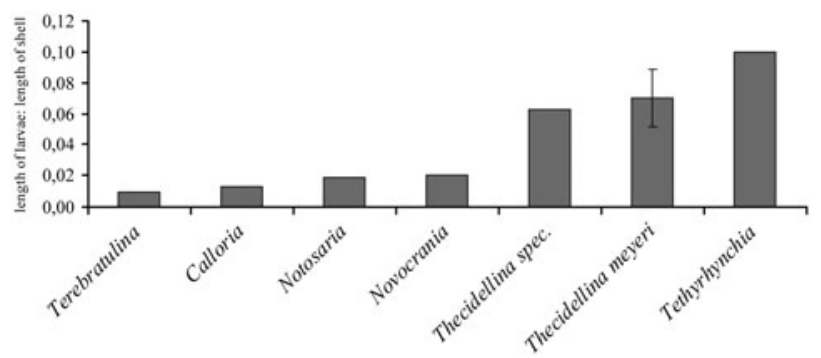

Fig. 6. Comparison of larval length/adult shell length ratios in different brachiopod species with lecithotrophic larvae. Measurements were taken from single individuals as representatives for the species, not representing statistically validated mean values; except for Thecidellina meyeri, there the mean value with standard deviation of ratios is given $(\mathrm{N}=35)$. Modified after Lüter, 2001.
Regarding the fact that the egg size is about the final size of the larva (personal observation), the size of the larvae given by James et al. (1992) is more than ten times smaller than observed in this study. Unfortunately, the data about the size of the larvae of Thecidellina barretti was never published (James et al., 1992). Compared to other brachiopods with lecithotrophic larvae the ratio of larval length to length of the adult in thecideides is among the largest found so far. It is second only to the minute brachiopod Tethyrhynchia mediterranea Logan from the Mediterranean (Lüter, 2001). The data obtained in this study, support the hypothesis of a negative correlation between larvae length and adult shell size in brachiopods, compared to their overall size (Figure 6).

Thecidellina meyeri was mentioned as T. ?barretti earlier by Jackson et al. (1971) in connection with the highest density of brachiopods $\left(10,600\right.$ specimens $\left.\mathrm{m}^{-2}\right)$ found in their study as part of communities in cryptic habitats in coral reefs, which agrees with our observations. In comparison Logan (1977) recorded a mean brachiopod density of Thecidellina cf. barretti of 4600 specimens $\mathrm{m}^{-2}$ in caves of the shallow terrace reef, Grand Cayman. Furthermore Jackson et al. (1971) described a bimodal distribution of the individual size of the specimens. Unfortunately the material investigated by Jackson and co-workers (1971) could not be found in any of the collections. However, the material investigated in this study confirmed the bimodal distribution of individual shell size. Based on this observation Jackson et al. (1971) postulated an annual release of the offspring/larvae and an overall span of life of about 2 years. However, a high juvenile mortality and a reduced growth after adolescence could also explain the pattern. Juvenile shells are very thin and thus erode very fast. Traces of their presence will soon disappear completely.

The dispersal ability of representatives of Thecidellina is not well understood. It is unknown what distances the passively drifting larvae of Thecidellina can travel. Additionally, representatives of Thecidellina show intensive internal brood care and dwell in cryptic habitats, which makes it even more difficult for the larvae to reach strong currents for passive long distance dispersal (Lüter et al., in press). On a larger timescale this would lead to allopatric speciation of Thecidellina on each distinct island, which might be reflected by the high diversity observed in the Caribbean.

The distribution of Thecidellina meyeri is restricted to the coral reefs of the ABC Islands. The species has, as yet, been found nowhere else in the Caribbean. However, thecideide communities consisting of a large number of individuals seem to allow at least for mid-range dispersal from island to neighbouring island, e.g. between Aruba and Curaçao (minimum distance: $100 \mathrm{~km}$ ), which could be explained by the use of in-between reefs as stepping stones. 


\section{ACKNDWLEDGEMENTS}

Special thanks go to D.L. Meyer (University of Cincinnati), who liberally donated the material this study was mainly based on. Many thanks to D. Eckhard, who did parts of the preparation of the material, measurements and photographs (extended focus) and to R.G. Moolenbeek (Zoölogisch Museum, Universiteit van Amsterdam), J. Thompson and D. Levin (National Museum of Natural History, Smithsonian Institution) for the loan of additional material. Special thanks to B. Leysner and A.O. Debrot (Carmabi Foundation) for providing colour plates of living specimens. We thank G. Drescher for technical assistance with processing the specimens for SEM investigations. Thanks are due to A. Logan (University of New Brunswick) and M.A. Bitner (Academy of Sciences, Warszawa) for kindly reviewing the manuscript. Financial support by the Deutsche Forschungsgemeinschaft (project: PHYLOTEC LU 839/3-1) is gratefully acknowledged.

\section{REFERENCES}

Coleman C.O. (2003) Digital inking: how to make perfect line drawings on computers. Organisms, Diversity and Evolution 3, 1-14, Electronic Supplement 14.

Cooper G.A. (1977) Brachiopods from the Caribbean Sea and adjacent waters. Studies in Tropical Oceanography 14, 1-212.

Dall W.H. (1885-1886) Reports on the Results of Dredging, under the Supervision of ALEXANDER AGASSIZ, in the Gulf of Mexico $(1877-87)$ and in the Caribbean Sea $(1879-80)$, by the U.S. Coast Survey Steamer 'Blake', Lieut.-Commander C.D. SIGSBEE, U.S.N., and Commander J.R. BARTLETT, U.S.N., Commanding. Report on the Mollusca-Part I. Brachiopoda and Pelecypoda. Bulletin of the Museum of Comparative Zoology (Cambridge) 12, 197-205.

Dall W.H. (1920) Annotated list of the Recent Brachiopoda in the collection of the United States National Museum, with descriptions of thirtythree new forms. Proceedings of the United States National Museum 57 , $261-377$.

Davidson T. (1864) On the Recent and Tertiary Species of Thecidium. The Geological Magazine 1, 12-22.

Jackson J.B.C., Goreau F. and Hartman W.D. (1971) Recent Brachiopod-Coralline sponge communities and their paleoecological significance. Science 173, 623-625.

James M.A., Ansell A.D., Collins M.J., Curry G.B., Peck L.S. and Rhodes M.C. (1992) Biology of living brachiopods. Advances in Marine Biology 28, 175-387.

Lacaze-Duthiers H. (1861) Histoire naturelle des brachiopodes vivants de la Méditerranée. I. Histoires naturelle de la Thecidie (Thecidium mediterraneum). Annales des Sciences Naturelles (La Zoologie), Series $415,259-330$.

Lee D.E. and Robinson J.H. (2003) Kakanuiella (gen. nov.) and Thecidellina: Cenozoic and Recent thecideide brachiopods from New Zealand. Journal of the Royal Society of New Zealand 33, 341-361.

Logan A. (1977) Reef-dwelling articulate brachiopods from Grand Cayman, BWI. In Taylor D.L. (ed.) Proceedings of the Third
International Coral Reef Symposium Volume 1: Biology, Rosenstiel School of Marine and Atmospheric Sciences, University of Miami, Miami, Florida, USA, May 1977, pp. 87-93.

Logan A. (1981) Sessile invertebrate coelobite communities from shallow reef tunnels, Grand Cayman, BWI. In Gomez E.D., Alcala A.C. and San Diego A.C. (eds) Proceedings of the 4th International Coral Reef Symposium Volume 2, Marine Science Center, University of the Philippines, Manila, Philippines, 18-22 May 1981, pp. 735-744.

Logan A. (1990) Recent Brachiopoda from the Snellius and Luymes Expeditions to the Surinam-Guyana Shelf Bonaire-Curaçao, and Saba Bank, Caribbean Sea 1966 and 1969-1972. Zoologische Mededelingen 63, 123-136.

Logan A. (1993) Recent Brachiopoda from Canarian-Cape Verdean Region: diversity, biogeographic affinities, bathymetric range and life habits. Courier Forschungsinstitut Senckenberg 159, 229-233.

Logan A. (2007) Geographic distribution of extant articulated brachiopods. In Selden P.A. (ed.) Treatise on invertebrate paleontology, part H: Brachiopoda, revised, Volume 6. Boulder and Lawrence: The Geological Society of America and University of Kansas Press, pp. 3083-3115.

Logan A. (in press) Recent thecideide brachiopods from the northwestern Pacific Ocean: systematics, life habits and ontogeny. Systematics and Biodiversity.

Lüter C. (2001) Larval brooding and development of the micromorph rhynchonellid Tethyrhynchia mediterranea (Brachiopoda: Recent). Journal of Marine Biology 81, 939-942.

Lüter C. (2005) The first Recent species of the unusual brachiopod Kakanuiella (Thecideidae) from New Zealand deep waters. Systematics and Biodiversity 3, 105-111.

Lüter C. (2007) Anatomy. In Selden P.A. (ed.) Treatise on invertebrate paleontology, part H: Brachiopoda, revised, Volume 6. Boulder and Lawrence: The Geological Society of America and University of Kansas Press, pp. 2321-2355.

Lüter C., Hoffmann J. and Logan A. (in press) Cryptic speciation in the Recent thecideide brachiopod Thecidellina in the Atlantic and the Caribbean. Transactions of the Royal Society of Edinburgh.

Pajaud D. (1970) Monographie des Thécidées (Brachiopodes). Mémoires de la Société Géologique de France (Nouvelle Série) 122, 1-345.

Richardson J.R. (1997) Ecology of articulate brachiopods. In Kaesler R.L. (ed.) Treatise on invertebrate paleontology, part $H$ : Brachiopoda, revised, Volume 1. Boulder and Lawrence: The Geological Society of America and University of Kansas Press, pp. 441-462.

and

Zumwalt G.S. (1970) The functional morphology of the tropical brachiopod Thecidellina congregata Cooper 1954. MS thesis. University of California, Davis, USA.

Correspondence should be addressed to:

Jana Hoffmann

Museum für Naturkunde der Humboldt-Universität zu Berlin Invalidenstrasse 43, 10115 Berlin, Germany email: jana.hoffmann@museum.hu-berlin.de 